Mycologia, 97(5), 2005, pp. 1093-1101.

(C) 2005 by The Mycological Society of America, Lawrence, KS 66044-8897

\title{
Development of an isolate-specific marker for tracking Phaeomoniella chlamydospora infection in grapevines
}

\author{
Hayley J. Ridgway ${ }^{1}$ \\ Johanna M. Steyaert \\ Brenda M. Pottinger \\ Margaret Carpenter \\ David Nicol \\ Alison Stewart \\ National Centre for Advanced Bio-Protection \\ Technologies, P.O. Box 84, Lincoln University, \\ Canterbury, New Zealand
}

\begin{abstract}
Petri disease causes decline of grapevines worldwide. The grapevine endophyte Phaeomoniella chlamydospora is the most important fungal pathogen associated with this disease. Epidemiological studies of this pathogen have been hampered by its common occurrence in the internal tissue of apparently healthy vines. Development of a molecular marker for a single strain would overcome this limitation and aid experiments designed to answer key questions about the biology of this pathogen. Genetic variation analysis of New Zealand and Italian strains of $P$. chlamydospora detected a potential molecular marker in New Zealand isolate A21. Characterization of the 1010 bp marker band showed that it had 50\% identity to $\operatorname{mox} Y$, a gene involved in the aflatoxin biosynthetic pathway of Aspergillus parasiticus. Sequencing of the region flanking the $1010 \mathrm{bp}$ product revealed a single nucleotide polymorphism in the $3^{\prime}$ border of the marker band. Primers were designed to amplify a $488 \mathrm{bp}$ fragment encompassing this polymorphic site and cleavage of this product with the restriction enzyme BsrI produced three bands only in isolate A21 and two bands in all other isolates tested. The sensitivity of the PCR-RFLP protocol was increased with a nested PCR approach and the protocol optimized for soil and wood samples. When the nested PCR/RFLP procedure was used to determine the persistence of viable and nonviable spores in soil, the results showed that nonviable spores were undetected after $8 \mathrm{wk}$ whereas viable spores still could be detected at $17 \mathrm{wk}$.
\end{abstract}

Key words: monooxygenase, Petri disease, Vitis vinifera

Accepted for publication 8 June 2005.

${ }^{1}$ Corresponding author. E-mail: ridgwh@lincoln.ac.nz

\section{INTRODUCTION}

Esca and esca-like syndromes are devastating diseases of mature vines in Europe and North America. The etiology of esca is not understood completely, but it appears to be a complex disease involving the succession of different fungi that culminate in an extensive white rot of the vine trunk (Mugnai 1999). Several fungi are associated with esca-affected grapevines, including Phaeomoniella chlamydospora, Phaeoacremonium aleophilum, to a lesser extent Pm. inflatipes. All species are isolated with a high frequency from discolored woody tissue of esca-affected vines, especially from brown or black longitudinal streaks, where marked gummosis of the xylem elements also occurs.

In recent years much research effort has been focused on species of Phaeoacremonium and Phaeomoniella and their involvement in the decline of young grapevines. $P$. chlamydospora has been implicated as the most important fungal organism associated with Petri disease (young grapevine decline) because of its predominance in affected grapevines. Grapevines with characteristic symptoms of Petri disease have been observed in South Africa (Ferreira et al 1994), United States (Morton 1997), Italy (Mugnai et al 1999), Australia (Pascoe and Cottral 2000) and New Zealand (Ridgway et al 2002). In separate pathogenicity studies, $P$. chlamydospora, Pm. aleophilum and $P m$. inflatipes have been shown to induce decline of young grapevines (Scheck et al 1998). P. chlamydospora, however, was isolated consistently from mature vines exhibiting brown wood-streaking from rooted grafted cuttings (Bertelli et al 1998), from black streaks and brown-red wood in esca diseased plants and in the rootstock of declining vines reported as suffering from Petri disease (Mugnai et al 1999). In New Zealand, P. chlamydospora and Pm. aleophilum both have been isolated from grapevines, but the former species is predominant.

Depending on vine age and physiological circumstances, grapevines infected with $P$. chlamydospora can exhibit a range of symptoms. Young vines grown from infected cuttings may have no obvious leaf symptoms or they may fail to thrive, be stunted and mildly chlorotic. Heavily infected vineyards are noticeably patchy with a mixture of stunted and healthy vines. Although Petri disease can cause a sudden collapse of young vines, more frequently there is slow decline with withering of leaves, dieback of some branches 
and stunted growth starting in the first year after planting (Bertelli et al 1998).

Due to a global increase in disease incidence, a number of research programs have been initiated to gain a greater understanding of the etiology, biology and epidemiology of $P$. chlamydospora. With traditional methods some information has been gained regarding its morphology, mode of reproduction, mode of dispersal and toxic metabolite production (Sparapano et al 2000, Tabachi et al 2000). Many hypotheses on the possible infection routes of $P$. chlamydospora have been suggested in the past few years. Mothervines may become infected by contamination of pruning wounds after harvesting of cuttings, indicating that rootstock cuttings taken from infected mothervines are a likely source of infection (Pascoe and Cottral 2000, Larignon 1999). P. chlamydospora also has been isolated from unpruned canes, suggesting that the fungus also can be spread with infected canes from the nursery. The occurrence of the pathogen in rooted grapevine cuttings supports this theory (Bertelli et al 1998). As P. chlamydospora also has been isolated from asymptomatic vines, questions have arisen about whether $P$. chlamydospora is an endophyte, a latent pathogen, a weak pathogen or a true vascular pathogen. In addition the mechanism by which $P$. chlamydospora causes decline is still under debate. Several phytotoxic metabolites isolated from $P$. chlamydospora have been identified and characterized but their role, if any, in pathogenesis remains unclear (Sparapano et al 2000, Tabacchi et al 2000).

Much of what has been elucidated about $P$. chlamydospora to date has been based on conventional morphological and pathogenicity studies. However molecular techniques have been helpful in the classification of $P$. chlamydospora into its present taxa. In 1998 DNA sequencing of the ITS region of $P$. chlamydospora confirmed the classification of this fungus (Dupont et al 1998, Crous and Gams 1999, Tegli et al 2000). Since then several studies have investigated the genetic variation of $P$. chlamydospora in isolates obtained from Italy, South Africa, New Zealand and the United States (Tegli et al 2000, Pottinger et al 2002). Such information has been useful in hypothesizing the possible mode of reproduction and spread of $P$. chlamydospora once introduced into a vineyard.

Molecular markers developed from genetic variation studies provide possibilities for distinguishing individuals within a species (Goldstein et al 2000) and therefore are valuable tools for identifying and monitoring $P$. chlamydospora populations. For example RAPD markers specific to isolates belonging to the pathotype P1 of Plasmodiophora brassicae were con- verted into a sequence characterized amplified region (SCAR). This reliable PCR-based marker allowed direct detection of pathotype P1 isolates from club roots consisting of a mixture of host and pathogen DNA (Manzanares-Dauleux et al 2000). Other studies have developed isolate-specific primers able to distinguish an isolate of the sclerotial mycoparasite Coniothyrium minitans. This PCR assay has been used to study the ecology of this potential biological control agent in the soil (Ridgway et al 2000).

The aim of the current study was to develop a robust isolate-specific marker for $P$. chlamydospora for use in experiments designed to track infection within grapevine wood or vineyard soil. The marker was tested for specificity against 53 isolates from New Zealand, Italy and Australia and optimized for sensitivity and suitability for detection in wood and soil samples.

\section{MATERIALS AND METHODS}

Maintenance of fungal isolates.-Fifty-three isolates of $P$. chlamydospora and four isolates of Pm. aleophilum were used in this study. This group comprised 39 isolates obtained from four regions in New Zealand, 10 isolates from four states in Australia and eight isolates from three regions in Italy (TABLE I). Isolates were cultured on potato-dextrose agar (PDA) (Difco Laboratories, Detroit, Michigan) at $22 \mathrm{C}$ with alternating $12 \mathrm{~h}$ light/ dark and stored as $0.5 \mathrm{~cm}^{2}$ mycelial plugs in $20 \%$ glycerol at $-80 \mathrm{C}$.

DNA extraction.-For genomic DNA (gDNA) extraction, a spore suspension from each isolate was streaked onto PDA and incubated 4-7 d at $22 \mathrm{C}$ in alternating $12 \mathrm{~h}$ light and dark conditions. Approximately 10-15 mycelial plugs $\left(0.5 \mathrm{~cm}^{2}\right)$ were added to $100 \mathrm{~mL}$ potatodextrose broth (PDB) (Difco Laboratories) and placed in an automatic shaker at $150 \mathrm{rpm}$, at approximately $20 \mathrm{C}$ for $7-10 \mathrm{~d}$. The mycelium was isolated from the PDB with sterile Miracloth (Calbiochem ${ }^{\circledR}$, La Jolla, California), pressed between paper towels to remove excess liquid and stored at -80 C. DNA was extracted from $0.1 \mathrm{~g}$ of the frozen ground mycelium using the PureGene DNA extraction kit (Gentra Systems, Minneapolis, Minnesota) according to manufacturer's instructions. The DNA pellet was rehydrated in $50 \mu \mathrm{L}$ of water and allowed to resuspend at $4 \mathrm{C}$ overnight. The quantity of gDNA was estimated by $1 \%$ agarose gel electrophoresis. All DNA samples were diluted to a working concentration of $10 \mathrm{ng} / \mu \mathrm{L}$.

UP-PCR amplification.-UP-PCR using primer 3-2 $\left({ }^{5^{\prime}}\right.$ TAAGGGCGGTGCCAGT ${ }^{3^{\prime}}$ ) (Bulat et al 2000) was performed in a $25 \mu \mathrm{L}$ reaction volume containing $10 \mathrm{mM}$ Tris $\mathrm{pH} 8.0,50 \mathrm{mM} \mathrm{KCl}, 200 \mu \mathrm{M}$ each of dGTP, dCTP, dATP, dTTP, $2.5 \mathrm{mM} \mathrm{MgCl}_{2}, 20$ pmoles of primer, $1.25 \mathrm{U}$ of Taq DNA polymerase (Roche Molecular Biochemicals, Mannheim, Germany) and $10 \mathrm{ng}$ 
TABLE I. Origin of the Phaeomoniella chlamydospora and Phaeoacremonium aleophilum isolates used in this study

\begin{tabular}{|c|c|c|}
\hline Isolate & Region & Rootstock \\
\hline $\mathrm{A} 1$ & Auckland, N.Z. & 3309 \\
\hline $\mathrm{A} 2$ & " & 3309 \\
\hline A3 & $"$ & 3309 \\
\hline $\mathrm{A} 4$ & $"$ & 3309 \\
\hline A5 & $"$ & Schwarzman \\
\hline A6 & $"$ & Schwarzman \\
\hline A7 & $"$ & $101-14$ \\
\hline A8 & $"$ & $101-14$ \\
\hline A9 & $"$ & $101-14$ \\
\hline $\mathrm{A} 10$ & $"$ & Schwarzman \\
\hline A11 & $"$ & 3309 \\
\hline A12 & $"$ & $101-14$ \\
\hline $\mathrm{A} 14$ & $"$ & $101-14$ \\
\hline A15 & $"$ & $101-14$ \\
\hline A16 & $"$ & $101-14$ \\
\hline A17 & $"$ & 3309 \\
\hline A18 & $"$ & 3309 \\
\hline A19 & $"$ & $101-14$ \\
\hline A20 & $"$ & 3309 \\
\hline A21* & $"$ & $101-14$ \\
\hline A22 & $"$ & Schwarzman \\
\hline A23 & $"$ & 3309 \\
\hline A24 & $"$ & $101-14$ \\
\hline A26 & $"$ & $101-14$ \\
\hline B1 & Blenheim (1), N.Z. & $101-14$ \\
\hline $\mathrm{B} 2$ & $"$ & Schwarzman \\
\hline B3 & $"$ & Schwarzman \\
\hline Bcb1 & Blenheim (2), N.Z. & 3309 \\
\hline Bcb2 & $"$ & 3309 \\
\hline Pch6 & Blenheim (3), N.Z. & 3309 \\
\hline Pch8 & $"$ & $5 \mathrm{C}$ \\
\hline Pch 21 & $"$ & $\mathrm{SO} 4$ \\
\hline Pch 34 & $"$ & $5 \mathrm{C}$ \\
\hline Pch35 & $"$ & 3309 \\
\hline Pch 66 & $"$ & $\mathrm{SO} 4$ \\
\hline G1 & Gisborne, N.Z. & $101-14$ \\
\hline G2 & $"$ & Riparia \\
\hline G3 & $"$ & $101-14$ \\
\hline $\begin{array}{l}\text { Linc. } \\
\text { Vine }\end{array}$ & Lincoln, Canterbury, N.Z. & 3309 \\
\hline Bb13 & Tuscany, Italy & Unknown \\
\hline Bb32 & $"$ & $"$ \\
\hline 191.95 & Umbria, Italy & $"$ \\
\hline 1091.95 & Veneto, Italy & " \\
\hline 22547 & Geelong, VIC, Australia & Pinot noir \\
\hline $22096 a$ & Irymple, VIC, Australia & Ramsey R3V1 \\
\hline $22018 \mathrm{a}$ & Evatt, ACT, Australia & Pinot noir \\
\hline 22925 & Padthaway, SA, Australia & Traminer \\
\hline 22695 & Irymple, VIC, Australia & $\begin{array}{l}\text { Cabernet } \\
\text { Sauvignon }\end{array}$ \\
\hline 22926 & Mudgee, NSW, Australia & Merlot \\
\hline 22544 & Kyneton, VIC, Australia & Riesling \\
\hline 22545 & $\begin{array}{l}\text { Great Western, NSW, } \\
\text { Australia }\end{array}$ & Riesling \\
\hline 22546 & Griffith, NSW, Australia & Zinfandel \\
\hline
\end{tabular}

TABLE I. Continued

\begin{tabular}{llc}
\hline \multicolumn{1}{c}{ Isolate } & \multicolumn{1}{c}{ Region } & Rootstock \\
\hline 22902b & $\begin{array}{c}\text { McClaren Vale, SA, } \\
\text { Australia }\end{array}$ & Grenache \\
& Tuscany, Italy & Unknown \\
157 & Abruzzi, Italy & $"$ \\
999.5 & Apulia, Italy & $"$ \\
334.T2.95 & Lombardy, Italy & \\
98.L.95 & "
\end{tabular}

* This isolate has been lodged in the Landcare Culture Collection, Auckland, NZ (http://www.landcareresearch. co.nz/research/biodiversity/fungiprog/icmp.asp).

genomic DNA. The cycling parameters were: denaturation at $94 \mathrm{C}$ for $5 \mathrm{~min}$, then 5 cycles of $94 \mathrm{C}$ for $50 \mathrm{~s}$, $52 \mathrm{C}$ for $2 \mathrm{~min}$ and $72 \mathrm{C}$ for $1 \mathrm{~min}$, followed by 34 cycles of $94 \mathrm{C}$ for $50 \mathrm{~s}, 52 \mathrm{C}$ for $90 \mathrm{~s}$ and $72 \mathrm{C}$ for $1 \mathrm{~min}$, with a final extension at $72 \mathrm{C}$ for $10 \mathrm{~min}$. UP-PCR products were viewed by $1 \%$ agarose gel electrophoresis.

Isolation of a marker band.-When isolate A21 was amplified with UP-PCR primer 3-2, a strongly amplified, unique $1 \mathrm{~kb}$ band was observed and identified as a potential molecular marker. This band was excised with a sterile $200 \mu \mathrm{L}$ pipette tip and used as template in a subsequent $25 \mu \mathrm{L}$ amplification reaction as described for primer 3-2. The PCR product was ligated into the pGEM-T vector (Promega Corporation, Madison, Wisconsin) according to manufacturer's instructions and transformed into Escherichia coli isolate INV $\alpha \mathrm{F}^{\prime}$ (Invitrogen Life Technologies, California). Clones containing an insert of the correct size were sent for sequencing to the Waikato DNA Sequencing Facility (University of Waikato, New Zealand). Primers specific to the $1 \mathrm{~kb}$ fragment were designed (MONO6 ${ }^{5}$ GCGGTGCCAGTTATGACAGAT $^{3^{\prime}}$ and MONO980 ${ }^{5^{\prime}}$ TCGCAACGTGAAGGAGCA $\left.^{3^{\prime}}\right)$ and used to amplify the marker band from a representative group of $P$. chlamydospora isolates. Each $25 \mu \mathrm{L}$ reaction contained $10 \mathrm{mM}$ Tris $\mathrm{pH} 8.0,50 \mathrm{mM}$ $\mathrm{KCl}, 200 \mu \mathrm{M}$ each of dGTP, dCTP, dATP, dTTP, $1.5 \mathrm{mM} \mathrm{MgCl}, 10$ pmoles of each primer, $10 \mathrm{ng}$ of genomic DNA and 1.25 U Taq DNA polymerase (Roche Molecular Biochemicals). Amplification consisted of $5 \mathrm{~min}$ at $94 \mathrm{C}$, followed by 35 cycles of $30 \mathrm{~s}$ at $94 \mathrm{C}, 30 \mathrm{~s}$ at $60 \mathrm{C}$ and $1 \mathrm{~min}$ at $72 \mathrm{C}$, followed by $7 \mathrm{~min}$ at $72 \mathrm{C}$. Amplimers were viewed by $1 \%$ agarose gel electrophoresis.

Extension of the marker sequence by inverse PCR (Ochman et al 1990).-Four hundred ng of A21 genomic DNA was digested with $10 \mathrm{U} \mathrm{NcoI} \mathrm{(New} \mathrm{England} \mathrm{Biolabs,} \mathrm{Beverly,}$ Massachusetts) in a total volume of $60 \mu \mathrm{L}$ for $4 \mathrm{~h}$ at 37 C. Complete digestion was confirmed by $1 \%$ agarose gel electrophoresis. The volume of the digested DNA was increased to $450 \mu \mathrm{L}$ with sterile water and the restriction enzyme extracted with an equal volume of phenol and chloroform. The digested DNA was precipitated with one-tenth volume of $3 \mathrm{M}$ sodium acetate and two volumes of $100 \%$ ethanol. The digested DNA 
was resuspended and self-ligated in a total volume of $150 \mu \mathrm{L}$ with $4 \mathrm{U}$ of T4 DNA ligase (Roche Molecular Biochemicals) at room temperature overnight. The ligated DNA was reprecipitated with one-tenth volume of $3 \mathrm{M}$ sodium acetate and two volumes of $100 \%$ ethanol and resuspended in $30 \mu \mathrm{L}$ of sterile water at a concentration of $10 \mathrm{ng} / \mu \mathrm{L}$. Fifty $\mathrm{ng}$ of $N c o$ I digested, self ligated DNA was used as the template in a PCR reaction containing $10 \mathrm{mM}$ Tris $\mathrm{pH} 8.0 ; 50 \mathrm{mM} \mathrm{KCl}$; $200 \mu \mathrm{M}$ each of dGTP, dCTP, dATP and dTTP; $1.5 \mathrm{mM}$ $\mathrm{MgCl}_{2} ; 10$ pmole of the inverse primers MONO13 ( ${ }^{5}$ TGCTCGTTCACGTTGCGAG ${ }^{3 \prime}$ ) and MONO946 $\left({ }^{5}\right.$ GATCAAACGCCTTGGTGGTC $\left.{ }^{3 \prime}\right)$ and $1.25 \mathrm{U}$ Taq DNA polymerase (Roche Molecular Biochemicals). PCR reactions were as described above, except the annealing temperature was $61 \mathrm{C}$ and the extension time within each cycle was $5 \mathrm{~min}$. The inverse PCR product was sequenced at the Waikato DNA Sequencing Facility (University of Waikato, New Zealand). Using the extended sequence, primers were designed to flank the $5^{\prime}$ and $3^{\prime}$ boundaries of the original $1 \mathrm{~kb}$ marker band. The amplified product was cloned into pGEM-T and sequenced from representative $P$. chlamydospora isolates.

PCR/RFLP analysis._-Primers MONO1475 ( ${ }^{5}$ GAT-

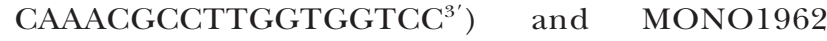
( ${ }^{5^{\prime}}$ ATTGCATCTTGCAAAGGGAC ${ }^{3 \prime}$ ) were designed to amplify a 489 bp fragment from all 53 P. chlamydospora isolates. Each $25 \mu \mathrm{L}$ reaction contained $10 \mathrm{mM}$ Tris pH 8.0; $50 \mathrm{mM} \mathrm{KCl;} 200 \mu \mathrm{M}$ each of dGTP, dCTP, dATP and dTTP; $1.5 \mathrm{mM} \mathrm{MgCl} 2 ; 10$ pmoles of each primer; $10 \mathrm{ng}$ of genomic DNA and 1.25 U Taq DNA polymerase (Roche Molecular Biochemicals). Amplification consisted of $5 \mathrm{~min}$ at $94 \mathrm{C}$, followed by 30 cycles of $30 \mathrm{~s}$ at $94 \mathrm{C}, 30 \mathrm{~s}$ at $60 \mathrm{C}$ and $30 \mathrm{~s}$ at $72 \mathrm{C}$, followed by $5 \mathrm{~min}$ at $72 \mathrm{C}$. Two microlitres of the $489 \mathrm{bp}$ PCR product was digested with $5 \mathrm{U}$ of $\mathrm{Bsr}$ (New England Biolabs) in a volume of $25 \mu \mathrm{L}$ at $65 \mathrm{C}$ for $3 \mathrm{~h}$. Restriction patterns were analyzed by $2 \%$ agarose gel electrophoresis.

Increased sensitivity of the PCR/RFLP protocol using nested PCR. - The sensitivity of the PCR/RFLP protocol was increased with a nested PCR protocol so that it could be used with environmental samples. Primers MONO1441 ( ${ }^{5^{\prime}}$ AGCAGGTGCTATGGAGTTTG $\left.{ }^{3^{\prime}}\right)$ and MONO2004 ( ${ }^{5^{\prime}}$ ATGCGTTCGAGGAAGGTATC $\left.{ }^{3 \prime}\right)$ were designed to amplify a 562 bp fragment encompassing the $489 \mathrm{bp}$ product used in the isolate-specific PCR/ RFLP protocol. Reaction conditions were as described for the $489 \mathrm{bp}$ product. Each PCR product (562 bp) was diluted 1:200 with sterile water and $1 \mu \mathrm{L}$ used as template in a secondary PCR with MONO1475/ MONO1962 as described above.

Sensitivity of the PCR/RFLP system.-Reaction sensitivity was determined with stepwise decreases in template concentrations from $5 \mathrm{ng}$ to $0.5 \mathrm{fg}$. Sensitivity was determined with both the standard and the nested PCR/RFLP protocols. To assess the sensitivity of the nested PCR/RFLP protocol in environmental samples, known quantities of $P$. chlamydospora DNA were added to a DNA solution extracted from wood and soil solutions that had tested negative for $P$. chlamydospora using a previously developed species specific PCR (results not shown) (Tegli et al 2000, Whiteman et al 2002). The ability of the primers to amplify species of Pm. aleophilum also was assessed with $10 \mathrm{ng}$ of purified Pm. aleophilum genomic DNA. Reaction conditions were as described above, except template for the primary PCR consisted of $500 \mathrm{pg}-5 \mathrm{fg}$ of A21 genomic DNA spiked with either $1 \mu \mathrm{L}$ soil or $1 \mu \mathrm{L}$ wood extract.

Detection of nonviable spores in soil.-Spores were produced for soil inoculation with a modification of the method of Tegli et al (2000). Typically the mycelium at the growing margin of the colony was sliced into $0.3 \mathrm{~cm}$ squares and 15-20 of these squares inoculated into $100 \mathrm{~mL}$ of potato-dextrose broth (PDB). The inoculated PDB was shaken at 125-150 rpm for 5-7 d at room temperature. Spores were harvested by filtering the broth through sterile Miracloth (Calbiochem ${ }^{\circledR}$ ) and concentrated from the filtrate by centrifugation at $3200 \mathrm{~g}$ for $5 \mathrm{~min}$. The concentration of the stock spore suspension was $1.5 \times 10^{8}$ spores per $\mathrm{mL}$. The germination percentage of these spores was assessed by plating onto PDA and determined to be $75 \%$. The viable treatment consisted of $10 \mu \mathrm{L}\left(1.5 \times 10^{6}\right.$ spores $)$ of this stock spore suspension combined with $250 \mathrm{~mL}$ sterile water and thoroughly mixed into $1.2 \mathrm{~kg}$ of dried soil to give a final concentration of $1.3 \times 10^{3}$ spores per g. Thus the final concentration of viable spores was $10^{3}$ spores per g. For the nonviable treatment, $10 \mu \mathrm{L}$ aliquots of the stock spore suspension were heated to $70 \mathrm{C}$ for $30 \mathrm{~min}$. The germination percentage of these spores was assessed by plating onto PDA and determined to be $0 \%$. Ten $\mu \mathrm{L}\left(1.5 \times 10^{6}\right.$ spores $)$ of the nonviable spore suspension also was combined with $250 \mathrm{~mL}$ sterile water and thoroughly mixed into $1.2 \mathrm{~kg}$ of dried soil to give a final concentration of $1.3 \times 10^{3}$ spores per $\mathrm{g}$. A control treatment, in which only $250 \mathrm{~mL}$ of sterile water was added to $1.2 \mathrm{~kg}$ of dried soil, also was included. Each treatment was replicated eight times and set up in a randomized block design in the shadehouse in early spring conditions. Two grams of soil was sampled from each pot at wk $0,1,3,8$ and 17 and stored at $-80 \mathrm{C}$ for analysis. DNA was extracted from the soil samples as described by Whiteman et al (2002) and tested for the presence of $P$. chlamydospora isolate A21 using the nested PCR/RFLP procedure.

\section{RESULTS}

Characterization of the isolate specific marker.-Of the 53 isolates tested, primer 3-2 produced a bright, clear and robust $1 \mathrm{~kb}$ amplimer (GenBank accession number AY921607) only in isolate A21 (FIG. 1) and this amplimer was identified as a potential isolate-specific marker. Reamplification and se- 


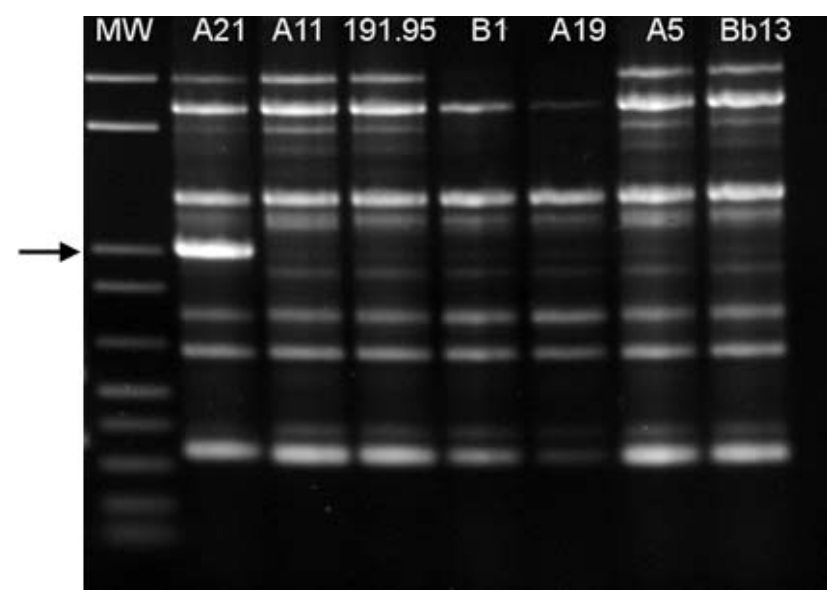

FIG. 1. Identification of a polymorphic band observed in isolate A21 shown by the arrow. MW designates the $1 \mathrm{~Kb}$ Plus DNA Ladder (Invitrogen, Carlsbad, California) and is shown at the left of the gel; isolate number is indicated above each lane.

quencing of the excised $1 \mathrm{~kb}$ amplimer revealed that the exact nucleotide length of the marker band was $1010 \mathrm{bp}$. The translated sequence showed that the predicted protein sequence had $39 \%$ identity to $\operatorname{mox} Y$, a gene in the aflatoxin biosynthesis pathway of Aspergillus parasiticus (FIG. 2). Similarity in amino acid residues was present over 269 (out of a possible 491) amino acids, or $54 \%$ of the translated sequence. Further BLAST protein searches indicated significant homology to a group of flavin-binding monooxygenase-like proteins, which contain a putative NADP binding site. Amplification with primers designed to areas within the $1 \mathrm{~kb}$ marker band revealed that this gene was present in all $53 P$. chlamydospora isolates and was not specific to isolate A21 (results not shown).

Identification of the polymorphism and development of the PCR/RFLP system. - Inverse PCR was used to extend the original $1 \mathrm{~kb}$ sequence by $500 \mathrm{bp}$ in both the $5^{\prime}$ and $3^{\prime}$ directions. Sequence alignment of representative $P$. chlamydospora isolates revealed that a single nucleotide polymorphism specific to isolate A21 occurred within the $3^{\prime}$ boundary of the original $1 \mathrm{~kb}$ fragment amplified by UP-PCR primer 3-2 . The polymorphism is silent and does not change the putative threonine encoded at this position (ACT $\rightarrow$ ACC). Analysis of the single nucleotide polymorphism present in genomic DNA sequence from isolate A21 showed that, together with the flanking nucleotides, it formed the $6 \mathrm{bp}$ recognition sequence (ACTG/GN) for the restriction enzyme $B s r I$. Primers were designed to flank this region and amplify a $489 \mathrm{bp}$ fragment from all 53 P. chlamydospora isolates. Digestion of this amplimer with the restriction enzyme BsrI produced three fragments (235, 136 and $118 \mathrm{bp}$ ) in isolate A21 and two fragments (371 and $118 \mathrm{bp}$ ) in the other 52 P. chlamydospora isolates (FIG. 3).

Sensitivity of the PCR/RFLP system.-Sensitivity of the PCR was improved from $5 \mathrm{pg}$ to $50 \mathrm{fg}$ for purified genomic DNA with the nested PCR protocol (FIG. 4). To determine whether this sensitivity would be robust when DNA was purified from environmental sources, the PCR was validated by spiking with DNA extracts from uninfected soil and wood. In both instances the sensitivity was maintained at $50 \mathrm{fg}$. Amplification of wood or soil extract with both sets of PCR primers showed that the amplification was specific to $P$. chlamydospora and did not co-amplify plant DNA or DNA from other organisms that inhabit soil or wood. The primers did not amplify Pm. aleophilum genomic DNA (FIG. 5).

Persistence of nonviable spores in soil using the isolatespecific PCR.-Nonviable P. chlamydospora spores could be detected in soil after $3 \mathrm{wk}$ but not after $8 \mathrm{wk}$ (TABLE II). Detection of viable spores declined after 8 wk and was detected only in half of the pots (four out of eight) at $17 \mathrm{wk}$.

\section{DISCUSSION}

Molecular markers for fungal plant pathogens such as $P$. chlamydospora are valuable tools in modern mycology and have been used successfully to gain a greater understanding of the evolution of pathotypes, gene flow, establishment of epidemics and discrimination of pathogen races and species (Stacey and Keen 1997). A species-specific marker has been developed for $P$. chlamydospora and used to detect this pathogen in vineyards (Tegli et al 2000, Ridgway et al 2002, Whiteman et al 2002). However detailed investigations of disease progression in simulated field situations have been confounded by the presence of the fungus in apparently healthy vines (Ridgway et al 2002). To overcome this limitation, a versatile and sensitive isolate-specific marker has been developed for a single $P$. chlamydospora isolate.

Of 53 isolates tested, a potential isolate-specific marker was identified in New Zealand isolate A21 with UP-PCR primer 3-2. For the marker to be of use in epidemiological studies it was important that the isolate was not biologically unusual because this may have affected its virulence and/or ecological behavior. Previous genetic variation studies using the AFLP 


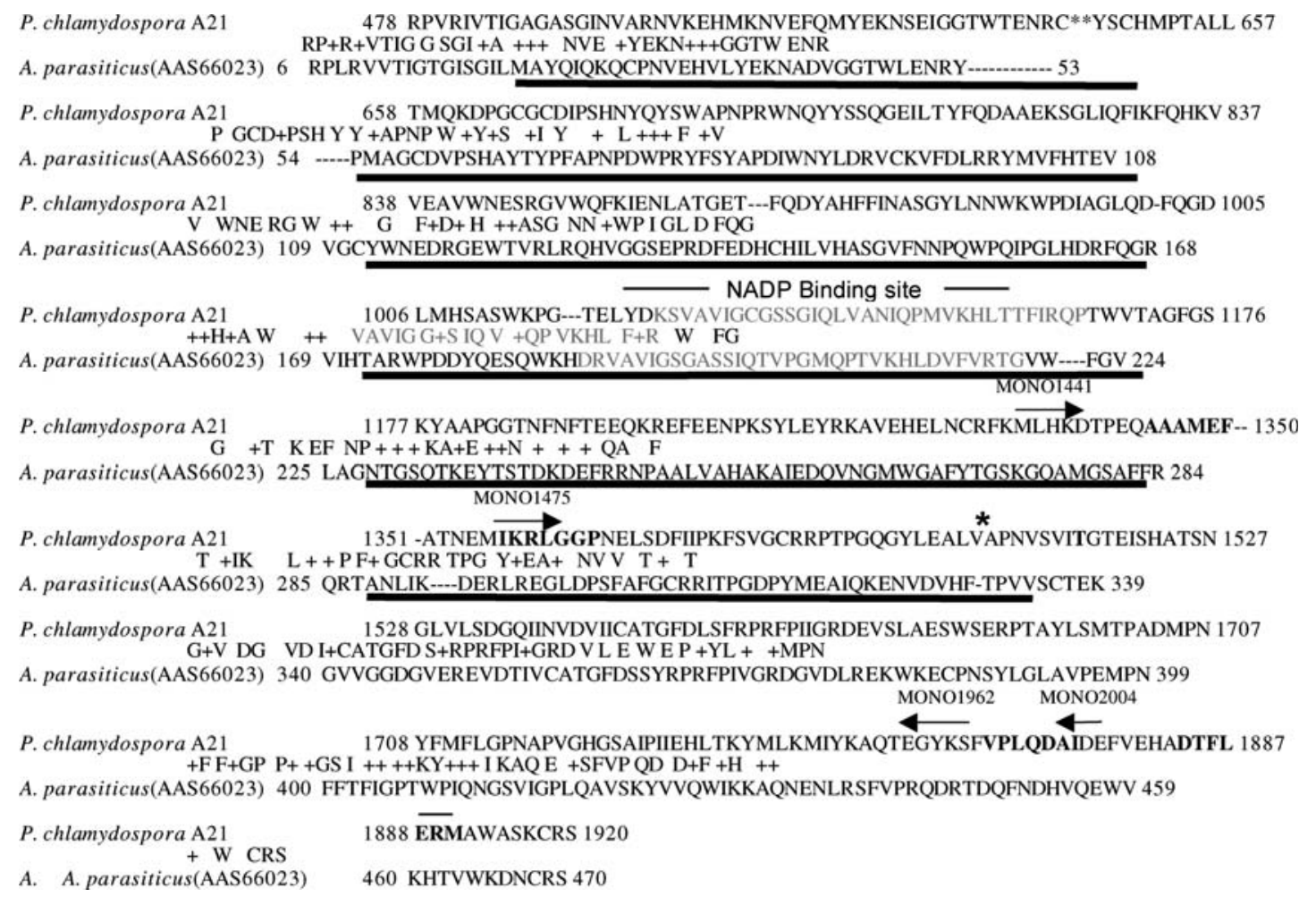

FIG. 2. Sequence homology between P. chlamydospora isolate A21 and Aspergillus parasiticus generated by a BLASTX analysis (http://www.ncbi.nlm.nih.gov/BLAST). The translated sequence of the extended molecular marker (2050 bp) is shown aligned with the corresponding amino acid sequences of $A$. parasiticus. The location of the amino acid encoded by the polymorphism is marked with an asterisk $(*)$. Identities $=193 / 491(39 \%)$, positives $=269 / 491(54 \%)$, gaps $=10 / 491(2 \%)$. Conservative substitutions are represented by $\mathrm{a}+$. The amino acid sequence corresponding to the position of the original $1010 \mathrm{bp}$ UP-PCR fragment is underlined. The position of the PCR primers with respect to the corresponding amino acid sequence is shown by an arrow $(\rightarrow)$.

technique indicated that isolate A21 fell within the range of genetic variability found in other New Zealand and Italian isolates (Pottinger et al 2002). Furthermore amplification of a $950 \mathrm{bp}$ region of the $1 \mathrm{~kb}$ marker band indicated that the DNA fragment was present in all P. chlamydospora isolates. Amplifi-

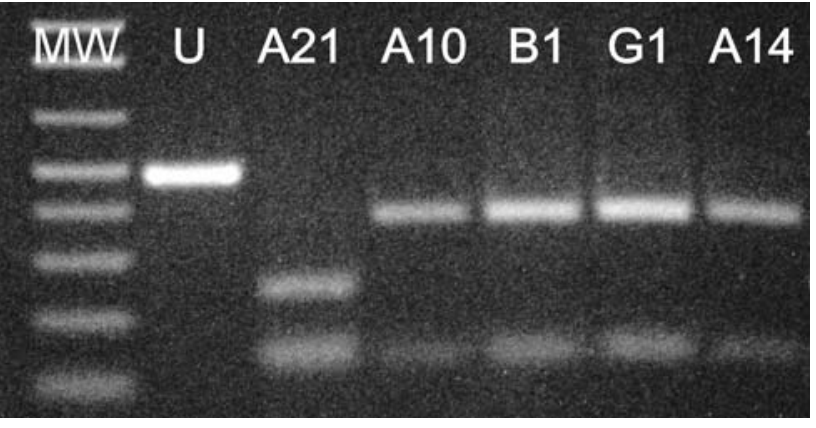

FIG. 3. Restriction digestion of the 489 bp fragment with $B s r$ I. Isolate numbers are shown above the gel, MW - $1 \mathrm{~Kb}$ Plus DNA ladder (Invitrogen, Carlsbad, California), U uncut fragment. cation of the regions flanking the marker band determined that a single nucleotide polymorphism in the $3^{\prime}$ binding site for UP-PCR primer 3-2 had generated the unique band. This substitution did not alter the encoded amino acid (threonine) or induce a frameshift within the predicted protein sequence. This provided further evidence that the isolate was likely to behave normally in the field as the polymorphism did not appear to confer a selective advantage or disadvantage by altered protein activity.

Database searches with the DNA sequence of the marker band indicated that the sequence had significant homology to flavin-binding monooxygenase-like proteins, including moxY of the Aspergillus parasiticus aflatoxin biosynthesis pathway. Monooxygenase enzymes are involved in the catabolism and anabolism of various primary and secondary metabolites in filamentous fungi, including several mycotoxin-biosynthetic pathways (Yu et al 1998). Several phytotoxic metabolites isolated from $P$. chlamydospora have been identified and characterized as $\alpha$-glucans 


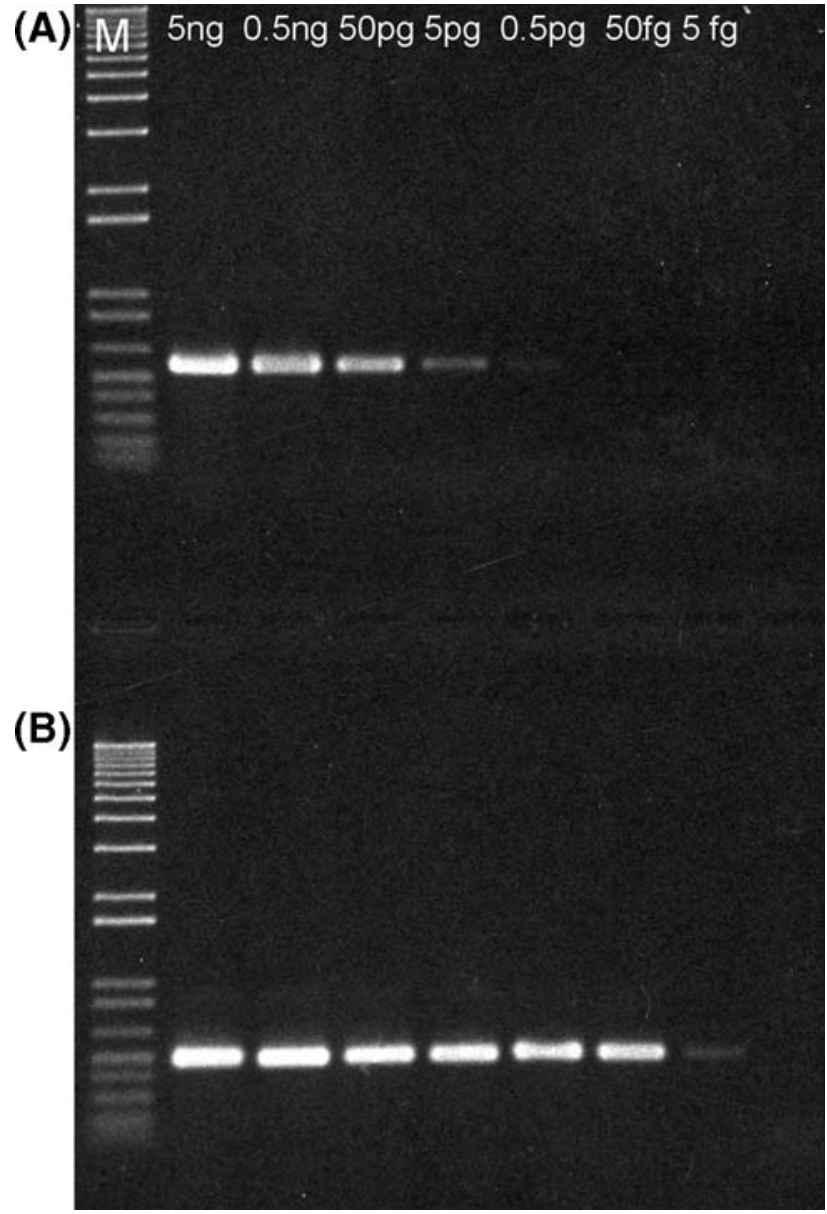

FIG. 4. Determination of the sensitivity of the PCR-RFLP protocol using purifed $P$. chlamydospora genomic DNA. DNA quantity is designated at the top of the gel. Far left lane: M-1 Kb Plus DNA ladder (Invitrogen, Carlsbad, California), (A) nonnested PCR, (B) nested PCR.

(pullalans) of various molecular weights (Sparapano et al 2000, Tabacchi et al 2000). The metabolites have been shown to produce foliar symptoms similar to those shown by declining vines, suggesting that at least some of the metabolites might be involved in pathogenesis and symptom expression in grapevines (Sparapano et al 2000). Other studies have isolated nine metabolites that have not been extensively tested but the simplest one, p-hydroxybenzaldehyde, has shown marked toxicity. Much more research is needed to determine the possible production of toxins and their role in the ecology of P. chlamydospora. However, given that genes encoding enzymes involved in toxin pathways are often found in biosynthetic clusters, the discovery of this monooxygenase gene may provide a valuable tool in the future characterization of toxin pathways in $P$. chlamydospora.
TABLE II. Number of soil samples $(\mathrm{n}=8)$ testing positive for $P$. chlamydospora using the nested isolate-specific PCR/ RFLP procedure

\begin{tabular}{cccc}
\hline \hline & \multicolumn{2}{c}{$\begin{array}{c}\text { Number of soil samples testing } \\
\text { positive for isolate A21 }\end{array}$} \\
\cline { 2 - 4 } $\begin{array}{c}\text { Time after } \\
\text { inoculation } \\
\text { (Week) }\end{array}$ & $\begin{array}{c}\text { Negative } \\
\text { control }\end{array}$ & Viable & Non-viable \\
\hline 0 & 0 & 8 & 8 \\
1 & 0 & 8 & 8 \\
3 & 0 & 8 & 5 \\
8 & 0 & 8 & 0 \\
17 & 0 & 4 & 0 \\
\hline
\end{tabular}

Specific digestion of the polymorphic site generated a predictable, unique banding pattern that was demonstrated to definitively identify isolate A21 from other $P$. chlamydospora isolates present in wood and soil. The primers were specific for $P$. chlamydospora and did not amplify DNA from Pm. aleophilum, a species which also has been implicated in Petri disease. The detection sensitivity of the isolate-specific PCR was $5 \mathrm{pg}$ and this compared well to the $1 \mathrm{pg}$ reported for the species-specific primers based on the ribosomal gene region that were designed by Tegli et al (2000) (Ridgway et al 2002). The nested PCR markedly improved sensitivity and a detection level of $50 \mathrm{fg}$ was achieved. This level of sensitivity is ideal for field detection purposes and will enable accurate detection of the marked isolate in inoculation experiments. The nested PCR is also considerably more rapid than traditional procedures, involving the isolation and culturing of the fungus from infected plant material, that are prolonged, laborious and inaccurate because the pathogen is slow growing and the process may take up to 2 mo (Mugnai et al 1999). In contrast the PCR-RFLP procedure can be performed in 1-2 d.

The applicability of the nested PCR-RFLP procedure for use in field experiments was tested with a simple experiment designed to determine how long spores of $P$. chlamydospora isolate A21 could persist in soil. It has been suggested by a number of researchers that the occurrence of the pathogen in nursery soil might act as a potential source of infection for rootstock mothervines and young vines in nursery beds, and there are also examples in the literature that $P$. chlamydospora is capable of infection via the root system of vines (Sidoti et al 2000). The results showed that the DNA from nonviable spores of $P$. chlamydospora were undetected after $56 \mathrm{~d}$ whereas DNA from soil inoculated with viable spores still was detected after $119 \mathrm{~d}$. This indicates that at least some $P$. chlamydospora spores could stay viable in the soil 


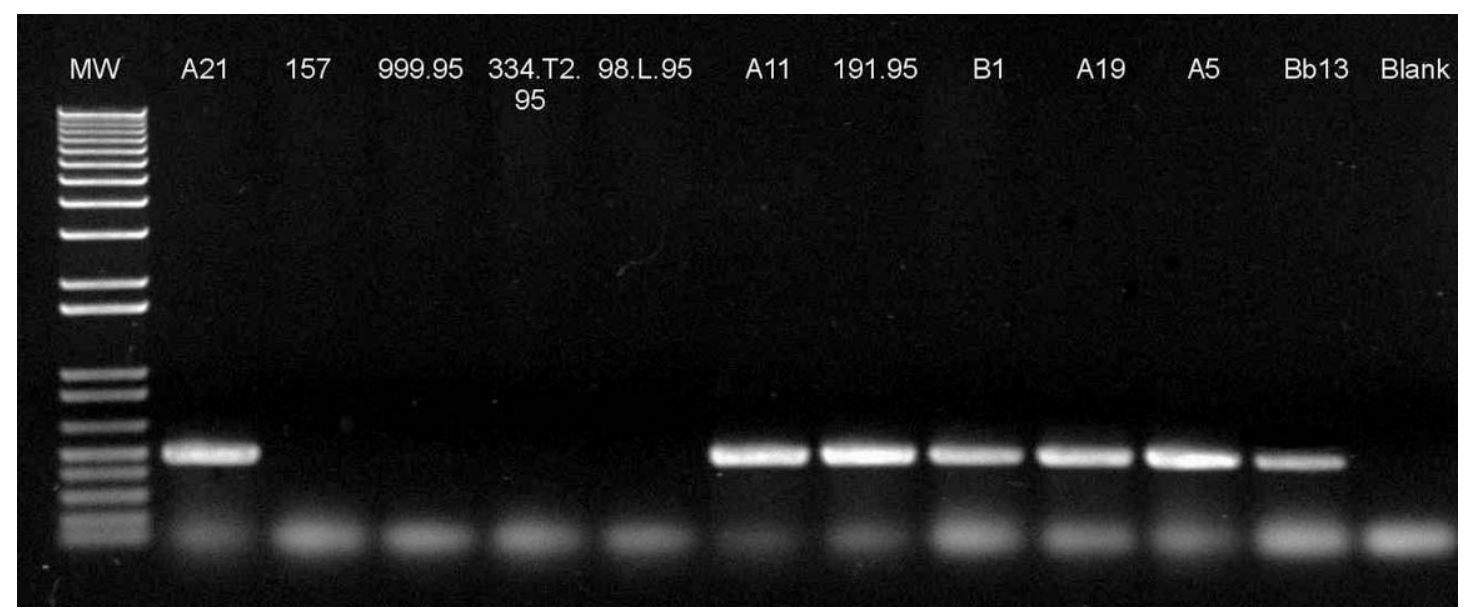

FIG. 5. PCR amplification of the $489 \mathrm{bp}$ fragment from seven isolates of P. chlamydospora and four isolates of Pm. aleophilum. Isolate numbers are shown above the gel, MW - 1 Kb Plus DNA ladder (Invitrogen, Carlsbad, California), Blank = negative control.

for $\sim 63 \mathrm{~d}(2 \mathrm{mo})$. However it is important to note that the sensitivity of this detection system is very good (50 fg) and that these positive results may correlate to as little as 1 spore per gram soil. The significance of this inoculum level in terms of threshold for infection is not yet well understood, however this information does indicate that spores can persist in soil and there is the possibility for inoculum build-up over time. Clearly the ability of spores to persist in soil also will depend on numerous other factors, such as soil moisture, physiochemical properties and microbiological activity.

In summary, prior experiments that investigated the spread of $P$. chlamydospora within vines and vineyards were hampered by the high degree of infection observed in apparently healthy vines. The use of the marked isolate with a protocol optimized for environmental samples will overcome this limitation. By using this marker, sophisticated experiments can be conducted to determine the pathogen's mode of dispersal and infection patterns in the viticultural context and provide a unique resource for future experiments designed to understand the lifecycle of this complex pathogen.

\section{ACKNOWLEDGMENTS}

This work was funded by a grant from the Foundation for Research, Science and Technology. The authors would like to thank Dr Sonia Whiteman (Lincoln University, New Zealand) Dr Ian Pascoe, Dr Jacky Edwards and Dr Eve Cottral (Institute for Horticultural Development, Australia) and Dr Laura Mugnai (Dipartimento Biotecnologie AgrariePatologia Vegetale, Italy) for contribution of fungal material.

\section{LITERATURE CITED}

Bertelli E, Mugnai L, Surico G. 1998. Presence of Phaeoacremonium chlamydospora in apparently healthy root grapevine cuttings. Phytopath Mediterrane 37:79-82.

Bulat SA, Lubeck M, Alekhina IA, Jensen DF, Knudsen IMB, Lubeck PS. 2000. Identification of a universally primedPCR-derived sequence-characterized amplified region marker for an antagonistic strain of Clonostachys rosea and development of a strain-specific PCR detection assay. Appl Environ Microbiol 66:4758-4763.

Crous PW, Gams W. 2000. Phaeomoniella chlamydospora gen. et comb. nov., a causal organism of Petri grapevine decline and esca. Phytopath Mediterrane 39:112118.

Dupont J, Laloui W, Roquebert MF. 1998. Partial ribosomal DNA sequences show an important divergence between Phaeoacremonium species isolated from Vitis vinifera. Mycol Res 102:631-637.

Ferreira JHS, van Wyk PS, Venter E. 1994. Slow dieback of grapevines: association of Phialophora parasitica with slow dieback of grapevines. SA J Enology Viticult 20:43-46.

Goldstein AL, Carpenter MA, Crowhurst RN, Stewart A. 2000. Identification of Coniothyrium minitans isolates using PCR amplification of a dispersed repetitive element. Mycologia 92:46-53.

Larignon P. 1999. Esca disease from a European perspective. In: Morton L, ed. Black Goo: symptoms and occurrence of grape declines. IAS/ICGTD Proceedings. Virginia, USA: International Ampelography Society. p 43-55.

Manzanares-Dauleux MJ, Barret P, Thomas G. 2000. Development of a pathotype specific SCAR marker in Plasmodiophora brassicae. Eur J Plant Pathol 106:781-787.

Morton L. 1997. Update on “Black goo." Wines and Vines 78:62-64.

Mugnai L, Graniti A, Surico G. 1999. Esca (black measles) 
and brown wood-streaking: two old and elusive diseases of grapevines. Plant Dis 83:404-418.

Ochman H, Nedhora MM, Garza D, Hartl DL. 1990. Amplification of flanking sequences by inverse PCR. In: Innis MAS, Gelfand DH, Sninsky JJ, White TJ, eds. PCR protocols: A guide to methods and applications. San Diego: Academic Press. p 219227.

Pascoe I, Cottral E. 2000. Developments in grapevine truck diseases research in Australia. Phytopath Mediterrane 39:68-75.

Pottinger B, Stewart A, Carpenter M, Ridgway HJ. 2002. Low genetic variation detected in New Zealand populations of Phaeomoniella chlamydospora. Phytopath Mediterrane 41:199-211.

Ridgway HJ, Sleight BE, Stewart A. 2002. Molecular evidence for the presence of Phaeomoniella chlamydospora in New Zealand vineyards and its detection in grapevine wood using species specific PCR. Australasian Plant Path 31:267-271.

— Stewart A. 2000. Molecular marker assisted detection of the mycoparasite Coniothyrium minitans A69 in soil. NZ Plant Protect 53:114-117.

Sheck HJ, Vasquez SJ, Gubler WD. 1998. First report of three Phaeoacremonium spp. causing young grapevine decline in California. Plant Dis 82:590.

Sidoti A, Buonocore E, Serges T, Mugnai L. 2000. Decline of young grapevines associated with Phaeoacremonium chlamydosporum in Sicily (Italy). Phytopath Mediterrane 39(1):87-91.

Sparapano L, Bruno G, Graniti A. 2000. Effects on plants of metabolites produced in culture by Phaeoacremonium chlamydsoporum, P. aleophilum and Fomitiporia punctata. Phytopath Mediterrane 39:169-177.

Tabacchi R, Fykerat A, Poliart C, Dubin G. 2000. Phytotoxins from fungi of esca of grapevine. Phytopath Mediterrane 39:156-161.

Tegli S. 2000. A hypothesis about the reproductive modes of Phaeoacremonium aleophilum and Phaeomoniella chlamydospora. Phytopath Mediterrane 39:289-298.

Whiteman SA, Jaspers MV, Stewart A, Ridgway HJ. 2002. Detection of Phaeomoniella chlamydospora in soil using species specific PCR. NZ Plant Protect 55:139-145.

Yu J, Chang P, Cary JW, Wright M, Bhatnagar D, Cleveland TE, Payne GA, Linz JE. 1995. Comparative mapping of aflatoxin pathway gene clusters in Aspergillus parasiticus and Aspergillus flavus. Applied Environ Microbiol 61:2365-2371. 